\title{
Heat shock protein 27 (HSP27) in patients with ovarian cancer
}

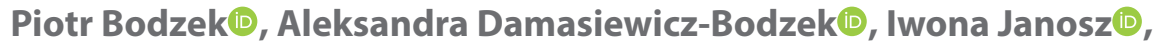 \\ Lukasz Witek(1), Anita Olejek(1)
}

Department of Gynaecology, Obstetrics and Oncological Gynaecology, Faculty of Medical Sciences in Zabrze Medical University of Silesia, Bytom, Poland

\begin{abstract}
Objectives: Ovarian cancer remains a very common cause of death among women worldwide. The cause is to be found in too late of a diagnostic process and therapeutic difficulties The presence of heat shock proteins in the serum of ovarian cancer patients is still a new area of study. It is necessary to continue studies on the possibilities for using these markers to predict a patient's response to a specific therapy and to monitor treatment progress.

Material and methods: The study included 52 women with ovarian cancer, hospitalised at the Department of Obstetrics, Gynaecology and Oncological Gynaecology, Medical University of Silesia. The control group consisted of 25 healthy women. The levels of HSP27 in the studied sera were determined by an immunoenzymatic method (ELISA).

Results: The mean concentration of HSP27 in the group of patients with ovarian cancer was significantly higher than in the control group of healthy women. We have shown that mean HSP27 levels in ovarian cancer patients increase with tumour progression and further depend on the clinical stage of the disease (FIGO). Positivity values analysis revealed in all clinical stages of ovarian cancer, excluding stage 1 , it was significantly higher than in the control group, and at the $4^{\text {th }}$ stage, it is significantly higher than at the $1^{\text {st }}, 2^{\text {nd }}$, and $3^{\text {rd }}$ stages. However, both for the untreated patients and those patients after chemotherapy, the mean HSP27 levels were significantly higher than in the control group.

Conclusions: Our studies indicate a significant contribution of HSP27 to the pathogenesis of ovarian cancer. It seems that serum HSP27 can be a marker for this cancer's development, and a marker for the clinical stage.
\end{abstract}

Key words: ovarian cancer; heat shock protein; HSP27

Ginekologia Polska 2021; 92, 12: 837-843

\section{INTRODUCTION}

Ovarian cancer remains a very common cause of death among women worldwide. The cause is to be found in too late of a diagnostic process and therapeutic difficulties [1]. Most women diagnosed with high stage ovarian cancer respond well to primary chemotherapy, but they usually succumb to a chemoresistant recurrence within two years [2]. Key to a significant improvement in ovarian cancer treatment results and prognoses is, therefore, finding efficient methods for the early diagnosis of this cancer and better understanding of the mechanisms responsible for drug resistance to standard chemotherapy. During ovarian carcinoma, an important role is played by the immune response directed against neoplastic cells, especially apoptosis. It is one of the key processes leading to the initiation of carcinogenesis [3].
Recently, an important role of heat shock proteins (HSPs) in the formation of malignant processes, including those within the ovary, has been found. This role mainly includes facilitating tumour transformation, increasing cancer cell survival and affecting anticancer drug resistance [4, 5]. One of the heat shock proteins strongly associated with carcinogenesis is HSP27. In addition to its role as a chaperone protein, it is also responsible for balancing the intracellular redox effect, cytoskeleton stabilisation and control of the internal cell differentiation and proliferation processes, as well as apoptosis and neoplastic transformation [6]. There is evidence that HSP27 protects cells from apoptosis-inducing stressors such as cytokines, ionizing radiation and oxidative stress [7]. Thus, on one hand, this protein protects a correct cell against the harmful effects of hypoxia or toxic physical and chemical agents. On the other, increased HSP27 activity 
induced by prolonged cellular stress may lead to inhibition of apoptosis, facilitating cell neoplastic transformation [8]. Furthermore, HSP27 may then protect transformed cancer cells from renaturing their cellular proteins which have been destroyed by cytostatic drugs used in treatment of cancer, which contributes to their increased malignancy and non-response to the drugs used [9].

Although, typically, heat shock proteins are located intracellularly, it is known that they can also be released into the extracellular space and peripheral circulation [10]. The role of extracellular HSPs has not been precisely determined so far. It has been shown, however, that circulating HSPs and/or anti-HSP antibodies can be useful carcinogenesis biomarkers, as well as prognostic factors affecting treatment outcomes [11]. The presence of HSPs in the serum of ovarian cancer patients is still a new area of study. It is necessary to continue studies on possibilities for using these markers to predict a patient's response to a specific therapy and to monitor treatment progress.

The aim of this study was, therefore, the evaluation of serum HSP27 levels in ovarian cancer patients in FIGO clinical stages I-IV according to histopathological type.

\section{MATERIAL AND METHODS}

The study included 52 women with ovarian cancer, hospitalised at the Department of Obstetrics, Gynaecology and Oncological Gynaecology, Medical University of Silesia. Patients with cardiovascular disease, diabetes mellitus, autoimmune diseases, etc. were excluded from the study. Twenty-five healthy women, of comparable age, were included in the control group.

Blood samples (ca. $5 \mathrm{~mL}$ vol.) were collected in the morning from antecubital veins. The sera obtained were stored at $-70^{\circ} \mathrm{C}$ until required for assays.

The Local Bioethics Committee of the Silesian Medical University approved the study protocol. All patients enrolled in the study were explained the study protocol and gave written informed consent to their participation.

The levels of the HSP27 in the studied sera were determined by an immunoenzymatic method (ELISA), using HSP27 (human) ELISA kits from Enzo Life Sciences (Farmingdale, NY, USA). The assay conditions and the procedure were in accordance with the manufacturer's recommendations. Determinations were conducted in duplicate, in one series.

The obtained results were subjected to statistical analysis. Normal distribution of the data was checked with the Shapiro-Wilk test. The groups were compared using the Kolmogorov-Smirnov test, the Mann-Whitney U-test, and the test of differences between structure indexes. For variability testing in the group of patients with ovarian cancer, the Kruskal-Wallis rank ANOVA test was used. Spearman's rank test was used for correlations. A p-value less than 0.05 was considered statistically significant. Calculations were performed with STATISTICA for Windows 10.0.

\section{RESULTS}

The mean age of women with ovarian cancer and healthy controls was comparable ( $55.8 \pm 10.1$ vs $53.1 \pm 7.2$ years). Of the 52 studied patients, ovarian cancer was diagnosed in 27 for the first time, i.e., they had not received any oncological treatment, while 25 patients had already undergone previous treatment with chemotherapy. Patients with clinical stage according to FIGO I-IV and with different histopathological forms of the tumour were recruited to the studied group (Tab. 1).

Table 2 presents the mean levels of HSP27 in both groups. The mean concentration of HSP27 in those patients with ovarian cancer was significantly higher than in the control group $(p=0.005)$. Positive results (values exceeding the mean +2 SD for the control group) were recorded in $42 \%$ of patients with ovarian cancer, and this ratio was significantly higher than in the control group.

\begin{tabular}{|c|c|}
\hline Clinical details & No (\%) \\
\hline \multicolumn{2}{|l|}{ Anti-cancer therapy } \\
\hline untreated so far & $27(51.9)$ \\
\hline after primary chemotherapy & $25(48.1)$ \\
\hline \multicolumn{2}{|l|}{ Histopathological type: } \\
\hline adenocarcinoma papillare serosum & $33(63.5)$ \\
\hline adenocarcinoma mucinosum & $8(15.4)$ \\
\hline adenocarcinoma endometrioides & $11(21.1)$ \\
\hline \multicolumn{2}{|l|}{ Clinical stage (FIGO): } \\
\hline 1 & $8(15.4)$ \\
\hline ॥ & $12(23.1)$ \\
\hline III & $24(46.1)$ \\
\hline IV & $8(15.4)$ \\
\hline
\end{tabular}

Table 2. Concentrations of Hsp27 in group of women with ovarian cancer and in control group

\begin{tabular}{|l|c|c|}
\hline & $\begin{array}{c}\text { Ovarian cancer } \\
\mathbf{n}=\mathbf{5 2}\end{array}$ & $\begin{array}{c}\text { Controls } \\
\mathbf{n = 2 5}\end{array}$ \\
\hline $\begin{array}{l}\text { HSP27 }(\mathrm{ng} / \mathrm{mL}) \\
\text { (mean } \pm \text { SD) }\end{array}$ & $50.17 \pm 57.59^{*}$ & $13.65 \pm 11.62$ \\
\hline $\begin{array}{l}\text { \% of positive results } \\
\text { (> mean }+ \text { 2SDs for } \\
\text { control group) }\end{array}$ & $42 \%^{*}$ & $4 \%$ \\
\hline
\end{tabular}

SD - standard deviation; ${ }^{*} p<0.05$ ovarian cancer vs controls 
The analysis of the mean levels of HSP27 in the patients with ovarian cancer, versus clinical stage of disease (FIGO), showed that these levels increased with the neoplastic process progress (Tab. 3). The mean HSP27 levels in patients at clinical stages II, III and IV were significantly higher than at stage I $(p=0.049, p=0.038$ and $p=0.0038$, respectively) and in the control group $(p=0.018, p=0.015$ and $p=0.0005$, respectively). The mean HSP27 levels in patients at stage IV was higher than at stages II $(p=0.009)$ and III $(p=0.015)$. Positivity values analysis revealed in all clinical stages of ovarian cancer, excluding stage I, it was significantly higher than in the control group, and at the IV stage, it is significantly higher than at the I, II, and III stages ( $p=0.027$, $p=0.039$ and $p=0.0183$, respectively) (Tab. 3 ).

The mean levels of HSP27 in the patients with ovarian cancer did not differ significantly depending on the cancer's histopathological type. In patients with adenocarcinoma papillare serosum and with adenocarcinoma endometrioides, the mean levels of this protein remained significantly higher compared to the control group $(p=0.004$ and $p=0.05$, respectively), while in patients with adenocarcinoma mucinosum it was comparable to that observed in the control group ( $p=0.48$ ) (Tab. 4). The positive value ratios for individual histopathological types of ovarian cancer were also comparable, and for adenocarcinoma papillare serosum and adenocarcinoma endometrioides significantly higher compared to the control group.
Use of primary chemotherapy did not result in a reduction in HSP27 levels, as the mean levels of this protein did not differ significantly between the group of patients previously subjected to anticancer treatment and the untreated group. The positive value ratios were also comparable in both groups of patients (Tab. 5). However, both in untreated patients and in patients after chemotherapy, the mean HSP27 levels were higher than in the healthy controls $(p=0.038$ and $p=0.0062$, respectively). A similar relationship was found for the positive value ratios.

In both studied groups of women - ovarian cancer patients and the control group of healthy women $-\mathrm{HSP} 27 \mathrm{lev}$ els were not correlated with age $(p=0.52, R=0.09$ and $p=0.84, R=0.04$, respectively).

\section{DISCUSSION}

Heat shock proteins are excessively expressed in many human malignant neoplasms. They participate in the proliferation of tumour cells, modify their growth, differentiation, and affect the occurrence of metastasis and modulate their death and recognition by the immune system [11, 12]. Some authors have pointed out that increased HSP activity is associated with poor prognosis in certain types of cancer, including ovarian cancer, and results in poorer response to treatment $[12,13]$. This raises the question of why HSP proteins change their activity in cancer cells. This may be due to reduced glucose levels, hypoxia, and $\mathrm{pH}$ changes within

\begin{tabular}{|c|c|c|c|c|c|}
\hline & \multicolumn{4}{|c|}{ Clinical stage (FIGO) } & \multirow{2}{*}{$\begin{array}{c}\text { Controls } \\
n=25\end{array}$} \\
\hline & $\begin{array}{c}1 \\
n=8\end{array}$ & $\begin{array}{c}\text { II } \\
n=12\end{array}$ & $\begin{array}{c}\text { III } \\
n=24\end{array}$ & $\begin{array}{c}\text { IV } \\
n=8\end{array}$ & \\
\hline $\begin{array}{l}\text { HSP27 [ng/mL] } \\
(\text { mean } \pm S D)\end{array}$ & $\begin{array}{l}13.41^{\text {a) b c c }} \\
\pm 17.65\end{array}$ & $\begin{array}{l}36.41 \text { d)f) } \\
\pm 30.62\end{array}$ & $\begin{array}{l}45.38^{\mathrm{e}} \text { f) } \\
\pm 50.29\end{array}$ & $\begin{array}{l}121.98^{f)} \\
\pm 78.91\end{array}$ & $\begin{array}{c}13.65 \\
\pm 11.62\end{array}$ \\
\hline \multirow{2}{*}{$\begin{array}{l}\% \text { of positive results } \\
\text { ( }>\text { mean }+2 S D \text { s for control group) }\end{array}$} & $13 \%$ & $42 \%{ }^{f)}$ & $38 \%{ }^{f)}$ & $88 \%{ }^{f(g)}$ & \multirow{2}{*}{$4 \%$} \\
\hline & $p=0.3576$ & $p=0.0034$ & $p=0.0033$ & $p=0.0000$ & \\
\hline
\end{tabular}

SD - standard deviation; ${ }^{\text {a) }} p<0.05$ I vs II; ${ }^{\text {b) }} p<0.05$ I vs III; ${ }^{\text {c) }} p<0.05$ I vs IV; ${ }^{\text {d) }} p<0.05$ II vs IV; ${ }^{\text {e) }} p<0.05$ III vs IV; ${ }^{\text {f) }} p<0.05$ II, III and IV vs controls; ${ }^{\text {g) }} p<0.05$ IV vs I, II and III

Table 4. Concentrations of Hsp27 in study group depending on histopathological type of tumour and in control group

\begin{tabular}{|c|c|c|c|c|}
\hline & \multicolumn{3}{|c|}{ Ovarian cancer } & \multirow[b]{2}{*}{$\begin{array}{c}\text { Controls } \\
n=25\end{array}$} \\
\hline & $\begin{array}{c}\text { adenocarcinoma } \\
\text { papillare serosum } \\
n=33\end{array}$ & $\begin{array}{c}\text { adenocarcinoma } \\
\text { mucinosum } \\
n=8\end{array}$ & $\begin{array}{c}\text { adenocarcinoma } \\
\text { endometrioides } \\
n=11\end{array}$ & \\
\hline $\begin{array}{l}\text { HSP27 [ng/mL] } \\
(\text { mean } \pm \text { SD) }\end{array}$ & $40.27^{*} \pm 59.45$ & $26.72 \pm 31.45$ & $44.79^{*} \pm 50.81$ & $\begin{array}{r}13.65 \\
\pm 11.62\end{array}$ \\
\hline \multirow{2}{*}{$\begin{array}{l}\% \text { of positive results } \\
(>\text { mean }+2 S \text { Ds for control group) }\end{array}$} & $42 \% *$ & $25 \%$ & $45 \% *$ & \multirow{2}{*}{$4 \%$} \\
\hline & $p=0.001$ & $p=0.072$ & $p=0.0023$ & \\
\hline
\end{tabular}

$\mathrm{SD}-$ standard deviation; ${ }^{*} \mathrm{p}<0.05$ ovarian cancer vs controls 
Table 5. Concentrations of Hsp27 in group of women with ovarian cancer depending on treatment phase and in control group

\begin{tabular}{|c|c|c|c|}
\hline & \multicolumn{2}{|c|}{ Phase of antineoplastic treatment } & \multirow{2}{*}{$\begin{array}{c}\text { Controls } \\
n=25\end{array}$} \\
\hline & $\begin{array}{l}\text { untreated so far } \\
\qquad n=27\end{array}$ & $\begin{array}{l}\text { after chemotherapy } \\
\qquad n=25\end{array}$ & \\
\hline $\begin{array}{l}\text { HSP27 }[\mathrm{ng} / \mathrm{mL}] \\
\text { (mean } \pm \text { SD) }\end{array}$ & $53.37^{*} \pm 55.54$ & $46.72^{*} \pm 60.68$ & $\begin{array}{c}13.65 \\
\pm 11.62\end{array}$ \\
\hline \multirow{2}{*}{$\begin{array}{l}\% \text { of positive results } \\
\text { ( }>\text { mean }+2 S D s \text { for control group) }\end{array}$} & $48 \% *$ & $36 \% *$ & \multirow{2}{*}{$4 \%$} \\
\hline & $p=0.0003$ & $p=0.0047$ & \\
\hline
\end{tabular}

SD — standard deviation; * $p<0.05$ ovarian cancer vs controls

the tumour. It may also be due to genetic changes associated with malignant transformation $[14,15]$. As mentioned above, HSPs play a role in apoptosis and show increased expression in cancer cells. Since cancer cells can be resistant to proapoptotic signals, HSP proteins are currently being investigated as potential therapeutic targets and diagnostic markers in cancer [16].

The heat shock protein possibly engaged in the carcinogenesis process is HSP27. This protein is excessively expressed in malignantly transformed endometrium [17] and is considered a marker for cervical squamous metaplasia [18]. Increased HSP27 expression was found in neoplastic tissue in the lungs, urinary bladder, kidneys, breast, oesophagus, liver, various cancers of the central nervous system and melanomas [19]. Anti-HSP27 antibodies were also found in women with endometrial, cervical, vaginal and vulvar cancers [20]. Studies on HSP27 expression in ovarian cancer are still scarce. It was shown that malignant ovarian cancers are characterised by significantly higher HSP27 levels in tumour tissues, versus a non-malignant neoplasm of that organ and untransformed ovarian cells [21]. It was also found that HSP27 expression in ovarian tumours increases with the neoplasm stage and is significantly higher in ovarian epithelial cancers with metastases to the peritoneum, versus tumours without such metastases [22]. In women with ovarian cancer, serum anti-HSP27 lgG antibody levels are significantly higher than in healthy women [20,23], and in specimens sampled from the cervix of women with ovarian cancer, anti-HSP27 IgA was found in almost $80 \%$ of cases [24]. The mechanism for producing antibodies against heat shock proteins in patients with a neoplasm is unclear, but the appearance of such antibodies suggests that during the malignant process its corresponding antigen (HSP27), a typical intracellular protein, is available in its extracellular form [25]. In nearly $40 \%$ of ovarian cancer patients, free HSP27, and HSP27-cytochrom c complexes in nearly $30 \%$ of these, can be found in specimens collected from the cervix (but only in $10 \%$ of patients with non-malignant lesions in the genital tract) [26]. Very little is known about the HSP27 levels in women with ovarian cancer, whereas increased values have already been found in the serum of patients with breast cancer [27] or pancreatic cancer [28]. In this last case, it has even been suggested that HSP27 (determined in the serum by ELISA) could be used as a new biomarker for early diagnosis of this neoplasm. In the studied group of women with ovarian cancer, the mean serum HSP27 level was significantly higher than in the control group, and in over $40 \%$ of cases reached values considered as positive. The mechanism for the release of heat shock proteins, including HSP27, into the extracellular space and circulation remains unknown. One of the possibilities is the transport of cytoplasmic HSPs together with other proteins containing transmembrane domains [29] or a direct HSP interaction with cellular membrane phospholipids [30]. Another possibility is HSP release from necrotic tumour cells [31]. The role of extracellular heat shock proteins in the pathogenesis of the malignant process is also not fully known. Extracellular HSP90 is considered to play a particularly significant role in neoplastic invasion (neoplastic cell angiogenesis, mobility and migration, formation of metastases) $[32,33]$. It seems that tumour cells are characterised by constitutive secretion of this protein, enabling them to invade tissues [34]. It is known that extracellular HSP27 acts as an anti-inflammatory stimulus inducing II-10 production by monocytes, and this may facilitate inhibition of TNF-alpha dependant apoptosis [35]. On the other hand, the immunogenic properties of extracellular HSPs may contribute to the development of the specific anticancer immunological response [36].

A very important issue is HSP27 expression during development of the neoplastic process, i.e., a study of the relationship between HSP27 levels and the disease's clinical progress. In other studies [37, 38], the more advanced the clinical stage (FIGO) of the disease, the lower the HSP27 expression (assessed by an immunohistochemical method) in the tumour tissues. Also, in the studies of Elpek et al. [39], HSP27 expression in tumour tissues was positively correlated with the cancer's FIGO clinical stage. Little is known, however, about the relationship between the clinical stage of ovarian cancer and the HSP27 levels in the serum. In the studied group of patients, the more advanced the disease's clinical stage, the higher the mean HSP27 levels in the patients' serum. Furthermore, in patients at clinical stage I, 
only $13 \%$ positive results were recorded, while in patients at stage IV, it was as much as $88 \%$. These observations may indicate increasing extracellular HSP27 expression during development of the malignant process. Increased circulating levels may reflect an increase in the active secretion of this protein into the extracellular space accompanying an increasing tumour mass or simultaneous intensified necrotic processes during cancer development and, thus, increased HSP27 release from damaged cells.

Heat shock protein expression may be modified according to the degree of tumour tissue differentiation. HSP27 expression seems to be related to higher malignant cell differentiation in endometrial cancers [40] and squamous cancers (uterine cervix, oral epithelium) [18,41], whereas in malignant astrocytomas/glioblastomas, on the contrary, there is lower cell differentiation [42]. This expression can also differ in histopathologically different tumours of the same organ. For example, in oesophageal cancers, HSP27 expression is reduced during carcinogenesis leading to adenocarcinoma [43] but increases during the development of squamous-cell carcinoma [44]. In the case of ovarian cancers, no significant differences were observed for HSP27 expression intensity and the histopathological cancer subtype in that organ [37]. In the studied group of ovarian cancer patients, mean serum HSP27 levels also did not differ significantly depending on the histopathological subtype of this cancer, similarly to the positive value ratios. This analysis disclosed, however, that in those patients with adenocarcinoma mucinosum, these levels were significantly lower and did not differ (similarly to the positive values ratio) from those observed in the control group. This may result from the fact that most mucinous ovarian tumours are diagnosed when they are low-grade (or borderline) and at an early stage.

HSP27's contribution to the development of tumour resistance to treatment, particularly to chemotherapy, is quite widely discussed. Excessive HSP27 expression is associated with the chemoresistance of breast tumours, head and neck cancers, oesophageal squamous-cell carcinoma and leukaemia [45]. It has been shown that in women with ovarian cancer, increased HSP27 activity can lead to resistance to chemotherapy [4], and after treatment it is not reduced significantly. Using an immunohistochemical method, it was observed that HSP27 expression is increased in $86 \%$ of cases before and in as many as $72 \%$ of cases after treatment with doxorubicin and cisplatin [46]. HSP27 overproduction also characterised cisplatin-resistant ovarian cancer cell lines in culture [47], while cytostatic drugs increased the activity of this protein in ovarian cancer cells [48]. The involvement of HSP proteins in the development of resistance of cancer tumours to chemotherapy is not fully known. HSP27 is a protective protein and thus likely has cytoprotective effects on cancer cells by "repairing" proteins that have been damaged by anti-cancer drugs $[45,49]$. However, most authors believe that the main mechanism of action of HSPs is to protect cancer cells from apoptosis. HSPs present in increased quantities react with the components of apoptotic pathways and, in consequence, promote the survival of cancer cells, additionally protecting them against mitochondrial damage [50]. HSP27 has been found to have a protective effect on cells against reactive oxygen species initiated by, among others, by TNF-a, which, depending on the level, may cause cellular apoptosis or necrosis [51]. Finally, HSP27 may protect the tumour microvasculature, as its presence is also found in vascular endothelial cells [52]. Our observations correspond to the results of the authors quoted above, as the mean levels of HSP27 in patients after chemotherapy and before treatment do not differ, with the positive value ratios also not differing. Thus, it can be concluded that the use of chemotherapy as an initial anticancer treatment does not affect extracellular HSP27 expression, or it only modifies its mechanism, e.g., from active secretion to release from necrotic cells. This issue, however, requires further studies to explain it.

HSP27 is also a candidate for an independent factor for deciding on the prognosis in some cancer types. Data on the relationship between HSP27 expression in tumour tissues and the prognosis and survival in ovarian cancers are contradictory. Most authors indicate a relationship between HSP27 expression and poorer survival prognosis [39, 53], however, there is data suggesting that intracellular expression of this protein can be a marker for longer survival [54, 55]. There is no data on a possible role for extracellular HSP27 as a prognostic marker for survival in ovarian cancer.

\section{CONCLUSIONS}

HSPs, including HSP27, can have different functions depending on their location: intracellular - cytoprotective, and extracellular - immunogenic $[16,29]$. From the point of view of development of the malignant process, this may be perceived as a paradox. On one hand, these proteins can, after cell transformation, facilitate neoplasm malignancy and its resistance to treatment. On the other hand, their extracellular forms may have a positive role in the development of a specific anticancer immunological response. Studies on the role of extracellular HSP27 in the development of the neoplastic process in cancer are still scarce. Our data indicates that expression of this form accompanies the development of epithelial ovarian cancers and increases with the advancing clinical stages of the cancer. The question about the role of this form in the development of the malignant phenotype and/or the host's anticancer response remains unanswered. Should it be the target for the therapy or is there support from an advantageous agent in fighting the cancer? Our studies indicate a significant contri- 
bution of HSP27 to the pathogenesis of ovarian cancer. It seems that serum HSP27 can be a marker for this cancer's development, and a marker of its clinical stage. However, as this protein can also be present in the serum of healthy people [56], it is necessary to establish the threshold level for a cut-off point which allows differentiation between the correct status and the disease when using sensitive quantitative techniques. The ELISA technique is good one for the quantitative assessment of serum HSP27 levels. Although diagnostic HSP27 levels have not yet been precisely specified, we can conclude the usefulness of this marker for assessing the clinical advancement of ovarian cancer and for the monitoring of treatment.

\section{Conflicts of interest}

None.

\section{REFERENCES}

1. Sienko J, Gaj P, Czajkowski $\mathrm{K}$, et al. Peroxiredoxin-5 is a negative survival predictor in ovarian cancer. Ginekol Pol. 2019; 90(1): 1-6, doi: 10.5603/GP.2019.0001, indexed in Pubmed: 30756364.

2. Zhao X, He M. Comprehensive pathway-related genes signature for prognosis and recurrence of ovarian cancer. PeerJ. 2020; 8: e10437, doi: 10.7717/peerj.10437, indexed in Pubmed: 33344083.

3. Mielczarek-Palacz A, Sikora J, Kondera-Anasz Z, et al. The immune complex p53 protein/anti-p53 autoantibodies in the pathogenesis of ovarian serous carcinoma. Ginekol Pol. 2020; 91(9): 519-253, doi: 10.5603/GP.a2020.0123, indexed in Pubmed: 33030731.

4. Hoter A, Naim HY. Heat shock proteins and ovarian cancer: important roles and therapeutic opportunities. Cancers (Basel). 2019; 11(9): 1389, doi: 10.3390/cancers11091389, indexed in Pubmed: 31540420.

5. Wu J, Liu T, Rios Z, et al. Heat shock proteins and cancer. Trends Pharmacol Sci. 2017; 38(3): 226-256, doi: 10.1016/j.tips.2016.11.009, indexed in Pubmed: 28012700.

6. Liu Z, Liu Y, Long Y, et al. Role of HSP27 in the multidrug sensitivity and resistance of colon cancer cells. Oncol Lett. 2020; 19(3): 2021-2027, doi: 10.3892/ol.2020.11255, indexed in Pubmed: 32194698.

7. Wantoch von Rekowski K, König P, Henze S, et al. Insight into cisplatin-resistance signaling of W1 ovarian cancer cells emerges mTOR and HSP27 as targets for sensitization strategies. Int J Mol Sci. 2020; 21(23): 9240, doi: 10.3390/ijms21239240, indexed in Pubmed: 33287446.

8. Sreedhar AS, Csermely P. Heat shock proteins in the regulation of apoptosis: new strategies in tumor therapy: a comprehensive review. Pharmacol Ther. 2004; 101(3): 227-257, doi: 10.1016/j.pharmthera.2003.11.004, indexed in Pubmed: 15031001.

9. Nappi L, Aguda AH, Nakouzi NAl, et al. Ivermectin inhibits HSP27 and potentiates efficacy of oncogene targeting in tumor models. J Clin Invest. 2020; 130(2): 699-714, doi: 10.1172/JCl130819, indexed in Pubmed: 31845908.

10. Costa-Beber LC, Hirsch GE, HeckTG, et al. Chaperone duality: the role of extracellular and intracellular HSP70 as a biomarker of endothelial dysfunction in the development of atherosclerosis. Arch Physiol Biochem. 2020 [Epub ahead of print]: 1-8, doi: 10.1080/13813455.2020.1745850, indexed in Pubmed: 32293198.

11. Taha EA, Ono K, Eguchi T. Roles of extracellular HSPs as biomarkers in immune surveillance and immune evasion. Int J Mol Sci. 2019; 20(18): 4588, doi: 10.3390/ijms20184588, indexed in Pubmed: 31533245.

12. Zhang Z, Jing J, Ye Y, et al. Characterization of the dual functional effects of heat shock proteins (HSPs) in cancer hallmarks to aid development of HSP inhibitors. Genome Med. 2020; 12(1): 101, doi: 10.1186/s13073020-00795-6, indexed in Pubmed: 33225964.

13. Chatterjee $S$, Burns TF. Targeting heat shock proteins in cancer: a promising therapeutic approach. Int J Mol Sci. 2017; 18(9), doi: 10.3390/ijms18091978, indexed in Pubmed: 28914774.

14. Dias TR, Samanta L, Agarwal A, et al. Proteomic signatures reveal differences in stress response, antioxidant defense and proteasomal activity in fertile men with high seminal ROS levels. Int J Mol Sci. 2019; 20(1): 203, doi: 10.3390/ijms20010203, indexed in Pubmed: 30626014.
15. Patinen $\mathrm{T}$, Adinolfi $\mathrm{S}$, Cortés $\mathrm{CC}$, et al. Regulation of stress signaling pathways by protein lipoxidation. Redox Biol. 2019; 23: 101114, doi: 10.1016/j.redox.2019.101114, indexed in Pubmed: 30709792.

16. Saini J, Sharma PK. Clinical, prognostic and therapeutic significance of heat shock proteins in cancer. Curr Drug Targets. 2018; 19(13): 1478-1490, doi: 10.2174/1389450118666170823121248, indexed in Pubmed: 28831912

17. Njoku $K$, Chiasserini $D$, Whetton $A D$, et al. Proteomic biomarkers for the detection of endometrial cancer. Cancers (Basel). 2019; 11(10): 1572, doi: 10.3390/cancers11101572, indexed in Pubmed: 31623106.

18. Jin Y, Kim SC, Kim HJ, et al. Use of protein-based biomarkers of exfoliated cervical cells for primary screening of cervical cancer. Arch Pharm Res. 2018; 41(4): 438-449, doi: 10.1007/s12272-018-1015-5, indexed in Pubmed: 29492827.

19. Heinrich JC, Donakonda S, Haupt VJ, et al. New HSP27 inhibitors efficiently suppress drug resistance development in cancer cells. Oncotarget. 2016; 7(42): 68156-68169, doi: 10.18632/oncotarget.11905, indexed in Pubmed: 27626687.

20. Korneeva I, Bongiovanni AM, Girotra M, et al. Serum antibodies to the $27-k d$ heat shock protein in women with gynecologic cancers. Am J Obstet Gynecol. 2000; 183(1): 18-21, doi: 10.1067/mob.2000.105431, indexed in Pubmed: 10920302.

21. Parcellier A, Schmitt E, Brunet M, et al. Small heat shock proteins HSP27 and alphaB-crystallin: cytoprotective and oncogenic functions. Antioxid Redox Signal. 2005; 7(3-4): 404-413, doi: 10.1089/ars.2005.7.404, indexed in Pubmed: 15706087.

22. Zhao M, Shen F, Yin YX, et al. Increased expression of heat shock protein 27 correlates with peritoneal metastasis in epithelial ovarian cancer. Reprod Sci. 2012; 19(7): 748-753, doi: 10.1177/1933719111432875, indexed in Pubmed: 22534325.

23. Olejek A, Damasiewicz-Bodzek A, Bodzek P, et al. Concentrations of antibodies against heat shock protein 27 in the sera of women with ovarian carcinoma. Int J Gynecol Cancer. 2009; 19(9): 1516-1520, doi: 10.1111/IGC.0b013e3181bf425b, indexed in Pubmed: 19955928.

24. Korneeva I, Bongiovanni AM, Girotra M, et al. IgA antibodies to the 27-kDa heat-shock protein in the genital tracts of women with gynecologic cancers. Int J Cancer. 2000; 87(6): 824-828, doi: 10.1002/1097-0215(20000915)87:6<824::aid-ijc11>3.0.co;2-k, indexed in Pubmed: 10956393.

25. Grotegut $P$, Hoerdemann PJ, Reinehr $S$, et al. Heat shock protein 27 injection leads to caspase activation in the visual pathway and retinal T-cell response. Int J Mol Sci. 2021; 22(2): 513, doi: 10.3390/ijms22020513, indexed in Pubmed: 33419223.

26. Korneeva I, Caputo TA, Witkin SS. Cell-free 27 kDa heat shock protein (hsp27) and hsp27-cytochrome c complexes in the cervix of women with ovarian or endometrial cancer. Int J Cancer. 2002; 102(5): 483-486, doi: 10.1002/ijc.10747, indexed in Pubmed: 12432550.

27. Wang $S$, Zhang $X$, Wang $H$, et al. Heat shock protein 27 enhances SUMOylation of heat shock protein $B 8$ to accelerate the progression of breast cancer. Am J Pathol. 2020; 190(12): 2464-2477, doi: 10.1016/j. ajpath.2020.04.012, indexed in Pubmed: 33222991.

28. Zhang S, Zhang Xq, Huang SI, et al. The effects of HSP27 on gemcitabine-resistant pancreatic cancer cell line through snail. Pancreas. 2015; 44(7): 1121-1129, doi: 10.1097/MPA.0000000000000418, indexed in Pubmed: 26348464.

29. Didelot $C$, Lanneau D, Brunet $M$, et al. Anti-cancer therapeutic approaches based on intracellular and extracellular heat shock proteins. Curr Med Chem. 2007; 14(27): 2839-2847, doi: 10.2174/092986707782360079, indexed in Pubmed: 18045130.

30. Arispe N, Doh M, Simakova O, et al. Hsc70 and Hsp70 interact with phosphatidylserine on the surface of $\mathrm{PC} 12$ cells resulting in a decrease of viability. FASEB J. 2004; 18(14): 1636-1645, doi: 10.1096/fj.04-2088com, indexed in Pubmed: 15522909.

31. Mambula SS, Calderwood SK. Heat induced release of Hsp70 from prostate carcinoma cells involves both active secretion and passive release from necrotic cells. Int J Hyperthermia. 2006; 22(7): 575-585, doi: 10.1080/02656730600976042, indexed in Pubmed: 17079215.

32. Sidera K, Patsavoudi E. Extracellular HSP90: an emerging target for cancer therapy. Current Signal Transduction Therapy. 2009; 4(1): 51-58, doi: 10.2174/157436209787048739.

33. Tsutsumi S, Neckers L. Extracellular heat shock protein 90: a role for a molecular chaperone in cell motility and cancer metastasis. Cancer Sci. 2007; 98(10): 1536-1539, doi: 10.1111/j.1349-7006.2007.00561.x indexed in Pubmed: 17645779. 
34. Li W, Sahu D, Tsen F. Secreted heat shock protein-90 (Hsp90) in wound healing and cancer. Biochim Biophys Acta. 2012; 1823(3): 730-741, doi: 10.1016/j.bbamcr.2011.09.009, indexed in Pubmed: 21982864.

35. de Azevedo-Santos AP, Rocha MC, Guimarães SJ, et al. Could increased expression of Hsp27, an "anti-inflammatory" chaperone, contribute to the monocyte-derived dendritic cell bias towards tolerance induction in breast cancer patients? Mediators Inflamm. 2019; 2019: 8346930, doi: 10.1155/2019/8346930, indexed in Pubmed: 31827382

36. Vulczak A, Catalão $\mathrm{CH}$, Freitas LA, et al. HSP-target of therapeutic agents in sepsis treatment. Int J Mol Sci. 2019; 20(17): 4255, doi: 10.3390/ijms20174255, indexed in Pubmed: 31480313.

37. Geisler JP, Tammela JE, Manahan KJ, et al. HSP27 in patients with ovarian carcinoma: still an independent prognostic indicator at 60 months follow-up. Eur J Gynaecol Oncol. 2004; 25(2): 165-168, indexed in Pubmed: 15032273.

38. Li KC, Heo K, Ambade N, et al. Reduced expression of HSP27 following HAD-B treatment is associated with Her2 downregulation in $\mathrm{NIH}$ :OVCAR-3 human ovarian cancer cells. Mol Med Rep. 2015; 12(3): 3787-3794, doi: 10.3892/mmr.2015.3876, indexed in Pubmed: 26044344.

39. Elpek GO, Karaveli S, Simşek T, et al. Expression of heat-shock proteins hsp27, hsp70 and hsp90 in malignant epithelial tumour of the ovaries. APMIS. 2003; 111(4): 523-530, doi: 10.1034/j.1600-0463.2003.111 0411.x, indexed in Pubmed: 12780528

40. Ioachin E. Immunohistochemical tumour markers in endometrial carcinoma. Eur J Gynaecol Oncol. 2005; 26(4): 363-371, indexed in Pubmed: 16122180.

41. Ajalyakeen $\mathrm{H}$, Almohareb $\mathrm{M}, \mathrm{Al}$-Assaf $\mathrm{M}$. Overexpression of heat shock protein 27 (HSP-27) is associated with bad prognosis in oral squamous cell carcinoma. Dent Med Probl. 2020; 57(3): 227-231, doi: 10.17219/dmp/119855, indexed in Pubmed: 32926599.

42. Yuan $\mathrm{Q}$, Cai HQ, Zhong Yi, et al. Overexpression of IGFBP2 mRNA predicts poor survival in patients with glioblastoma. Biosci Rep. 2019; 39(6): BSR20190045, doi: 10.1042/BSR20190045, indexed in Pubmed: 31138764.

43. Soldes OS, Kuick RD, Thompson IA, et al. Differential expression of Hsp27 in normal oesophagus, Barrett's metaplasia and oesophageal adenocarcinomas. Br J Cancer. 1999; 79(3-4): 595-603, doi: 10.1038/sj.bjc.6690094, indexed in Pubmed: 10027336.

44. Lambot MA, Peny MO, Fayt l, et al. Overexpression of 27-kDa heat shock protein relates to poor histological differentiation in human oesophageal squamous cell carcinoma. Histopathology. 2000; 36(4): 326-330, doi: 10.1046/j.1365-2559.2000.00858.x, indexed in Pubmed: 10759946.

45. Ciocca DR, Calderwood SK. Heat shock proteins in cancer: diagnostic, prognostic, predictive, and treatment implications. Cell Stress Chaper- ones. 2005; 10(2): 86-103, doi: 10.1379/csc-99r.1, indexed in Pubmed: 16038406.

46. Arts $\mathrm{HJ}$, Hollema $\mathrm{H}$, Lemstra W, et al. Heat-shock-protein-27 (hsp27) expression in ovarian carcinoma: relation in response to chemotherapy and prognosis. Int J Cancer. 1999; 84(3): 234-238, doi: 10.1002/(sici)1097-021 5(19990621)84:3<234::aid-ijc6>3.0.c0;2-9, indexed in Pubmed: 10371339.

47. Yamamoto $K$, Okamoto A, Isonishi S, et al. Heat shock protein 27 was up-regulated in cisplatin resistant human ovarian tumor cell line and associated with the cisplatin resistance. Cancer Lett. 2001; 168(2): 173-181, doi: 10.1016/s0304-3835(01)00532-8, indexed in Pubmed: 11403922.

48. Tanaka $\mathrm{Y}$, Fujiwara $\mathrm{K}$, Tanaka $\mathrm{H}$, et al. Paclitaxel inhibits expression of heat shock protein 27 in ovarian and uterine cancer cells. Int J Gynecol Cancer. 2004; 14(4): 616-620, doi: 10.1111/j.1048-891X.2004.14409.x, indexed in Pubmed: 15304155.

49. Moutaoufik MT, Tanguay RM. Analysis of insect nuclear small heat shock proteins and interacting proteins. Cell Stress Chaperones. 2021; 26(1): 265-274, doi: 10.1007/s12192-020-01156-3, indexed in Pubmed: 32888179.

50. Beere HM. Death versus survival: functional interaction between the apoptotic and stress-inducible heat shock protein pathways. J Clin Invest. 2005; 115(10): 2633-2639, doi: 10.1172/JCI26471, indexed in Pubmed: 16200196.

51. Qi Z, Shen $L$, Zhou H, et al. Phosphorylation of heat shock protein 27 antagonizes TNF- $a$ induced HeLa cell apoptosis via regulating TAK1 ubiquitination and activation of p38 and ERK signaling. Cell Signal. 2014; 26(7): 1616-1625, doi: 10.1016/j.cellsig.2014.03.015, indexed in Pubmed: 24686082.

52. Gawad A, Ptak-Belowska A, Brzozowski T, et al. Monocytes and vascular endothelial cells apoptosis. Role of p-HSP27. J Physiol Pharmacol. 2009; 60(4): 55-61, indexed in Pubmed: 20065497.

53. Piura B, Rabinovich A, Yavelsky V, et al. Heat shock proteins and malignancies of the female genital tract. Harefuah. 2002; 141(11): 969-972, indexed in Pubmed: 12476632.

54. Könsgen D, Klinkmann G, Kaul A, et al. Soluble heat-shock protein 27 in blood serum is a non-invasive prognostic biomarker for ovarian cancer. Eur J Obstet Gynecol Reprod Biol. 2020; 255: 154-159, doi: 10.1016/j. ejogrb.2020.10.044, indexed in Pubmed: 33130378.

55. Annunziata CM, Kleinberg L, Davidson B, et al. BAG-4/SODD and associated antiapoptotic proteins are linked to aggressiveness of epithelial ovarian cancer. Clin Cancer Res. 2007; 13 (22 Pt 1): 6585-6592, doi: 10.1158/1078-0432.CCR-07-0327, indexed in Pubmed: 18006758.

56. De AK, Roach SE. Detection of the soluble heat shock protein 27 (hsp27) in human serum by an ELISA. J Immunoassay Immunochem. 2004; 25(2): 159-170, doi: 10.1081/ias-120030525, indexed in Pubmed: 15162919. 